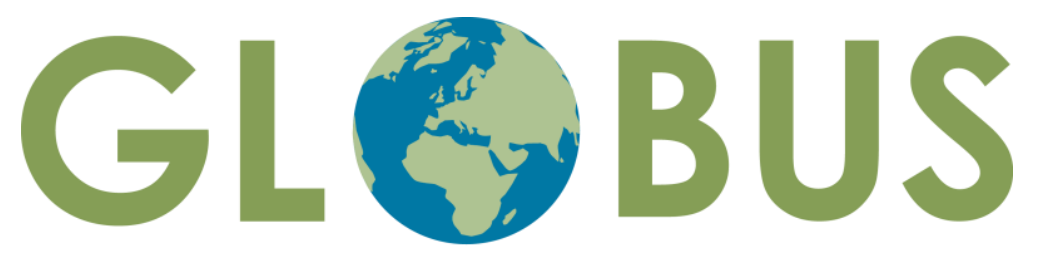

Reconsidering European Contributions to Global Justice

\title{
Global Justice and Aid Effectiveness Reforms of the European Union's Development Policy
}

Johanne Døhlie Saltnes

GLOBUS Research Papers

03/2019 - October 2019 
Johanne Døhlie Saltnes

Global Justice and Aid Effectiveness: Reforms of the European Union's

Development Policy

GLOBUS Research Paper 3/2019

October 2019

(C) Johanne Døhlie Saltnes

GLOBUS Research Papers (online) | ISSN: 2535-2504

http://www.globus.uio.no/publications/globus-research-papers/

Johanne Døhlie Saltnes is Postdoctoral Fellow at ARENA Centre for European Studies, University of Oslo

Reconsidering European Contributions to Global Justice (GLOBUS) is a research project that critically examines the EU's contribution to global justice.

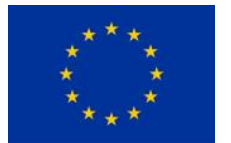

Funded by the European Union's Horizon 2020 programme. This work is the sole responsibility of the author. It does not reflect the opinion of the EU. The Research Executive Agency is not responsible for any use that may be made of the information it contains.

\section{www.globus.uio.no}

E Twitter: @globus_h2020

f Facebook: @globus.h2020

Issued by:

ARENA Centre for European Studies

University of Oslo

P.O. Box 1143 Blindern

0318 Oslo, Norway

www.arena.uio.no

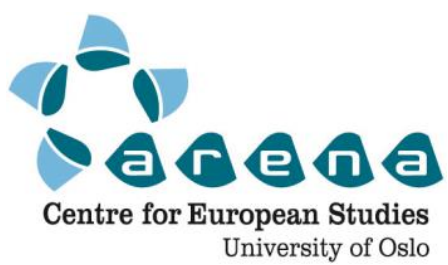




\section{Abstract}

In this paper, I recast the story of the like-minded's intermediate resistance and subsequent acceptance of the EU's aid effectiveness reforms from one of competing interests and identities to one of contestation over the normative principles that should guide aid effectiveness reforms. I draw on the GLOBUS conception of justice as impartiality to conceptualise central elements of the EU's development policy, and further on the concepts of justice as mutual recognition and justice as non-domination to understand the like-minded's resistance to the EU's approach. The paper further highlights the usefulness of applying a global justice perspective when studying the EU's development policy, as it facilitates a move beyond so-called 'idealist motivations' for aid and creates analytical standards that nuance our understanding of the competing normative claims that donors make in their aid policies.

\section{Keywords}

Aid effectiveness, donor coordination, EU development policy, global justice, norm contestation, ownership 


\section{Introduction ${ }^{1}$}

Development aid $^{2}$ is a policy of redistribution that affects the conditions for global justice. While the principal aim of aid is sustainable development and ending poverty worldwide, 3 the practice of providing development cooperation comes with a risk of domination. Among the central critiques of aid are claims that it has served the interests of Western countries by means of getting access to valuable natural resources in developing countries (Charnoz \& Severino, 2007; Hayter, 1971). Others claim that aid creates perverse impacts on developing countries such as contributing to keep corrupt leaders in power or distorting markets so that developing countries are trapped in an aid curse (Easterly, 2006; Moyo, 2009). Moreover, scholars, civil society organisations and politicians have all pointed to the problem of ineffective aid and the excessive transaction costs that come with the provision of aid (Action Aid International, 2005; Easterly \& Pfutze, 2008; Short, 2000). When the European Commission launched an aid effectiveness initiative in February 2007, European Commissioner for Development Louis Michel emphasised the risk of aid becoming a burden for developing countries:

It is abnormal that a finance minister in a developing country receives on average two hundred missions from money lenders a year, whereas in Kenya, money lenders purchase medicines by way of 13 bodies responsible for tenders! Aid has to improve things and not become a burden.

(Agence Europe 2007)

As a response to the various critiques of aid, donors embarked upon a process of reforming their principles and practices at the turn of the millennium. This wider reform agenda is known as the aid effectiveness agenda and the Development Assistance Committee (DAC) of the Organisation for Economic Co-operation and Development (OECD) 4 has been the principal organisational driver of this reform process. The European Union (EU) and its member states, which together account for more than $50 \%$ of the world's aid flows, also played an important role in shaping these aid effectiveness reforms. In particular, the so-called like-minded countries (the Nordics,

\footnotetext{
${ }^{1}$ I would like to thank Helene Sjursen, Erik Oddvar Eriksen, Kjartan Koch Mikalsen and Solveig Aamodt for helpful comments on earlier drafts of this paper. I am also grateful for comments by participants at a GLOBUS workshop in Oslo (2018) and the workshop 'Trade, development and global justice' at Wits University, Johannesburg (2017). This paper draws on an earlier publication in the Journal of European Integration (Saltnes, 2019)

2 The terms 'aid', 'development cooperation' and 'Official Development Assistance' (ODA) will hereinafter be used interchangeably.

3 i.e. as defined by the globally agreed Agenda 2030 and the Sustainable development goals. See: https://www.globalgoals.org.

4 Most of the large donors are members of the DAC, including the European Union. Exceptions include the BRICS states and Arab countries such as United Arab Emirates.
} 
the United Kingdom, Ireland and the Netherlands) have taken a central role in establishing aid effectiveness reforms (Elgström \& Delputte, 2016; Olsen, 2013; Selbervik \& Nygaard, 2006). However, the like-minded countries have also resisted aid effectiveness reforms proposed by the Commission in the EU context. In the literature, this resistance towards common EU development policy initiatives has been argued to result from a wish to maintain national control (Carbone, 2008, 2013a, 2013b, 2017; Horký, 2012; Orbie \& Lightfoot, 2017) or due to identity-conflicts (Delputte \& Orbie, 2014; Delputte \& Söderbaum, 2012; Elgström \& Delputte, 2016; Smith, 2013). But, the fact that the like-minded ended up agreeing to the EU's policies suggests that there might be reasons, other than those connected to control and identity, which can explain these countries' initial resistance to the EU's aid effectiveness reforms.

In this paper I study the like-minded countries' initial resistance and subsequent acceptance of the EU's aid effectiveness reform. I do so by tracing the like-minded states' role as drivers of the EU's development policy from a global political justice perspective. I draw on the GLOBUS conception of justice as impartiality to conceptualise central elements of the EU's development policy, and further on the concepts of justice as mutual recognition and justice as non-domination to understand the like-minded's resistance to the EU's approach. In line with recent critical constructivist research on norm contestation, I emphasise the role of competing ideas about how to counter the dominating practices that follows from the increasingly complex system of global aid distribution (Krook \& True, 2012; Puetter \& Wiener, 2007; Saltnes, 2019; Wiener, 2019). While the goal is agreed upon, I show that there are different interpretations among EU member states regarding how aid effectiveness reforms should be constructed. The aim is, first, to analyse the extent to which and why the like-minded's contestation of the EU's aid effectiveness reforms concern questions of global justice. Second, I discuss the limits and ambiguities in the EU's approach from a global justice perspective.

The following section sets out the analytical framework and discusses the three GLOBUS conceptions of justice as well as how these conceptions are applied to the case of aid effectiveness reforms. The paper proceeds with a discussion of the method and case selection applied in the paper. I focus on the EU's donor coordination reform which aimed at reducing unjust transaction costs for aid beneficiaries and to establish a coordination system whereby donors would distribute aid more evenly. The goal was to avoid some beneficiaries receiving huge amounts of funds while others receive little, which is often referred to as the 'aid darling - aid orphan' problem. Then, an in-depth empirical investigation of the like-minded states' resistance to, and subsequent acceptance of, the EU's donor coordination initiative is conducted. The analysis shows that the like-minded's resistance can be understood as a contestation of not including recipients in the reform process. Ultimately, I discuss limits and ambiguities with regard to the like-minded's interpretation of such ownership from a global justice perspective. 


\section{Analytical framework}

Resistance to integration in EU development policy has already been subject to some investigation. The literature has proposed two main explanations of resistance; first, drawing on rationalist theory, a number of scholars have argued that donors are concerned with retaining control over aid policies because aid can be used as leverage to secure economic and security interests (Carbone, 2008, 2013a, 2013b, 2017; Horký, 2012; Orbie \& Lightfoot, 2017). Second, drawing on role theory, another group of scholars have suggested that like-minded states have resisted EU initiatives due to competing donor identities. In their view, the like-minded member states have a self-understanding as multilateralists that competes with and inhibits their commitment to a strong EU profile on development issues (Delputte \& Orbie, 2014; Delputte \& Söderbaum, 2012; Elgström \& Delputte, 2016; Smith, 2013). This literature has contributed to our understanding of resistance to integration in the realm of development. However, it is less convincing in accounting for why, after a period of resistance and reluctance, the likeminded countries have accepted the EU's proposals. Hence, in order to fully understand the like-minded's initial resistance and subsequent acceptance, this paper's starting point is the hypothesis that competing ideas of how to achieve aid effectiveness contributed to the like-minded's resistance (Saltnes, 2019).

I propose an analytical framework that can disentangle such competing ideas about aid reforms and how to achieve aid effectiveness. To do so, I draw on three conceptions of global political justice, as developed by the GLOBUS project (Eriksen, 2016; Sjursen, 2017). 5 The three conceptions are not mutually exclusive but are helpful to tease out different priorities regarding how aid effectiveness reforms could be constructed. Starting from the argument that arbitrary rule is the essence of injustice (Laborde, 2010; Pettit, 2010) the conceptions emphasise different solutions regarding how to reduce domination.

Global justice as non-domination considers the state to be responsible for protecting individuals against arbitrary power. It builds on the assumption that states, which effectively balance their citizens' opinions and interests, co-exist and treat each other with mutual respect. The free individual is protected by the 'undominating and undominated state' (Eriksen, 2016; Pettit, 2010). States, on behalf of its citizens, operate in the international system and negotiate and make agreements with other states on issues that require action beyond state borders. Avoiding dominance of one state over another must be secured through international law and human rights regulations, in ways that respect the principles of equality and non-interference. To secure the respect for non-intervention, cooperation at the global level could be established through multilateral institutions. Multilateralism would enable deliberation and coordination among states, but would remain voluntary: 'the role of global institutions is thus to

\footnotetext{
5 The starting point is that dominance is the essence of injustice. The three conceptions of global political justice are solutions that would secure freedom from the arbitrary wielding of power, or dominance, in different ways. These conceptions prioritise differently and therefore have different strengths and weaknesses when it comes to protecting the freedom of individuals.
} 
promote common global reasons and to foster deliberation and critical dialogue, not to legally sanction non-compliance' (Eriksen, 2016, p. 10). According to this conception of justice, aid would be provided out of a duty of beneficence rather than a legal obligation. Further, the donor state would be the rightful claimant to decide how and where to provide aid.

In line with this conception of justice we would expect to see support for aid effectiveness reforms based on a multilateral approach where all actors are given a chance to participate. In order to gain support for reforms at the EU level, they would have to align with the broader multilateral initiatives in place. Further, reforms would be voluntary and states would remain in charge of the decision on how and to what extent to participate in the reforms, in line with the principle of non-intervention. Freedom of the individual is best protected within the state structure.

The conception of global political justice as impartiality calls for stronger international institutions and effective legal instruments that can be enforced when states fail to ensure the freedom of its citizens. What is needed is a neutral arbitrator to prevent dominance among states. The main units of concern are individual human beings and the protection of human rights is prioritised over states sovereignty (Eriksen, 2016). In order to secure the freedom of individuals, it is necessary to establish a neutral standard that can regulate colliding interests, values and norms within and between states. Actors would have a moral duty to ensure redistribution on a global scale. This is best secured by giving power to an impartial third party. A supranational agent could tame domestic interests and pressure unwilling states to change policies, i.e. by the use of economic sanctions (Dworkin, 2011). According to this conception of justice, domestic control over aid could be trumped out of a concern for eliminating dominance globally. When facing issues that transcend borders and affect citizens across states, legal structures and institutions are needed to enhance 'the ability of individuals to influence those decisions that affect them' (Sjursen, 2017, p. 8). Justice as impartiality reflects the view that 'without a higher-ranking third party that can interpret and make the abstract idea of equal freedom effective, dominance is unavoidable' (Eriksen, 2016, p. 15)

In line with this conception of justice, we would expect to see states giving up national control over reform policies and agreeing to let institutions outside the state regulate how reforms in the international aid distribution system should be carried out. In the case of aid effectiveness, justice as impartiality would prioritise a supranational solution over intergovernmental multilateralism. The idea that a neutral and unbiased supranational policy is needed to make sure that coordination among donors is effectively carried out would be central. Reforms in line with justice as impartiality would include referring powers to a supranational agent that had the means to pressure unwilling states to coordinate.

Ultimately, the conception of global political justice as mutual recognition shifts the focus from generic solutions that are acceptable for all, to the need for recognising difference. This conception focuses on the fact that actors are different and that they 
may adhere to a number of different and competing but equally reasonable values. To secure global justice it is necessary to give all perspectives a due hearing. Only by making sure that all relevant actors are given the possibility to argue their position it is possible to determine what a just solution requires. It may therefore be necessary to adopt different solutions for different actors in order to obtain equal treatment. In the realm of aid and development the need to recognise difference is well manifested in political discourse. Ayittey's (2010) call for 'African solutions for African problems' is one such manifestation. The aid effectiveness agenda also mirrors this call with its continuous and increasing focus on ownership of development policies (OECD 2005, 2008). Ownership can be defined as 'the degree of control recipient governments are able to secure over implemented policy outcomes' (Whitfield \& Fraser, 2009, p. 4). The concern for ownership emphasises the need for all actors affected by the policy to have a say.

In line with a conception of justice as mutual recognition we would expect to find that the most affected groups would be given a due hearing in the reform process. This could be visible, for instance, by emphasising the ownership principle in the process of conducting aid effectiveness reforms. This would reflect the view that the particular interests and experiences of the beneficiaries are central to the aim of rectifying dominance.

\section{Context and methodology}

Some recent literature has pointed to the central role of the so-called like-minded member states in determining the direction of EU development policy (Elgström, 2016; Elgström \& Delputte, 2016). The starting point for like-minded cooperation was the Utstein alliance formed by the all-female development ministers Clare Short (the United Kingdom), Evelina Herfkens (the Netherlands), Heidemarie Wieczorek-Zeul (Germany) and Hilde Frafjord Johnsen (Norway) in the Utstein Abbey in Norway in 1999. The 'gang of four' represented, at the time, 27 per cent of the OECD's total aid and their alliance played a key role in shaping the global aid agenda. Many of what later became the central principles of the aid effectiveness agenda emerged from the cooperation and exchange of ideas in the Utstein alliance (Development Today 2006).

Following from the works of the Utstein alliance, a loosely organised network of coordination among like-minded countries emerged. This group is also known as the Nordic Plus and they developed several documents of best practices on aid effectiveness throughout the first decade of the new millennium. The like-minded aimed at coordinating donor practices within the group, and harmonisation among donors is a central goal in the Nordic Plus group's documents (Nordic Plus 2005, 2006, 2007).

The like-minded countries' role as agenda setters in global development discourse has been acknowledged in the literature. Scholars have used terms such as 'Nordic exceptionalism' (Olsen, 2013; Selbervik \& Nygaard, 2006) 'humane internationalists' (Pratt, 1989; Stokke, 1989) and value-driven 'norm entrepreneurs' (Ingebritsen, 2002; Lawler, 2007; Olsen, 2013) when analysing the like-minded countries role in the realm of development. The strength of the like-minded group's agenda-setting power has led 
Elgström and Delputte (2016, p. 2) to conclude that 'today, a core group of like-minded countries, including the Nordics, are the main driving forces behind European aid convergence'. They have also been characterised as 'instrumental in the preparatory discussions for the 2005 Paris Declaration on Aid Effectiveness' (Brouwers, Kliest and Limonard, 2008, p. 29).

The central characteristics of the like-minded states' position to global development include a strong emphasis on multilateralism and recipient ownership, conceiving development relations as a partnership (Odén \& Wohlgemuth, 2007), keeping the goal of poverty eradication as the main goal for development policy (Elgström \& Delputte, 2016), human rights and good governance as a centrepiece of all development practices (rights-based approach) (Elgström \& Delputte, 2016; Lawler, 2007; Odén \& Wohlgemuth, 2007; Olsen, 2013; Selbervik \& Nygaard, 2006), and enhancing harmonisation and coordination among donors with the goal of reducing transaction costs and unfortunate consequences of global aid.

In this paper, I investigate the internal contestation over the EU's aid effectiveness reforms from a novel angle. My starting point is the observation that there were different interpretations among EU member states regarding how aid effectiveness reforms should be constructed. In order to structure the analysis I make use of a global political justice perspective and I seek to answer the following questions: To what extent and why did the like-minded's contestation over the EU's aid effectiveness reforms concern questions of justice? Are there limits and ambiguities to the EU's approach? I engage with these questions through a case-study of the Commission's proposal to enhance coordination and harmonisation among EU donors. The EU's policy on aid coordination is known as the 'Code of conduct on complementarity and division of labour' (Council 2007). ${ }^{6}$ The policy was negotiated in the Council's development working group, CODEV, in 2006 and spring 2007 during the Austrian, Finnish and German presidencies of the Council and was adopted as Council Conclusions by the General Affairs and External Relations Council (GAERC) on 15 May 2007. The case is selected on grounds of its centrality in the EU's proposed aid effectiveness reforms. It proposed concrete reforms with regards to the member states' policies and sought to rectify one of the major challenges in global aid, aid fragmentation, through a less dominating and more effective global aid system. The code of conduct also served to inform the EU's subsequent aid effectiveness reforms, inter alia the 2009 operational framework on aid effectiveness (Council 2009).

Through this qualitative analysis of the like-minded states' contestation and subsequent acceptance of the EU's code of conduct, the paper seeks to recast the story of the like-minded's resistance from one of competing interests and identities to one of competing interpretations of sustainable development and aid effectiveness.

${ }^{6}$ Hereinafter: the code /the code of conduct 
The three conceptions of justice provide a systematic framework for assessing the extent to which the discussions of the EU's aid effectiveness initiative concerned questions of global justice. Further, the added value of using a global justice perspective is the possibility it provides to distinguish the different ideas and arguments regarding solutions for how to achieve sustainable development and rectify the unwanted consequences of increasing levels of global aid. The conceptions of justice are ideal types that are used to develop a set of expectations and requirements to evaluate the likeminded countries contestation and arguments for acceptance of the EU's reform proposals. The analysis also contributes to our understanding of why the like-minded states resisted aid effectiveness reforms and ultimately accepted the EU code of conduct by looking at the actors' different and colliding views the negotiations of the reform.

To allow for data verification and triangulation, data was collected from a variety of sources. The analysis builds on 17 semi-structured interviews with representatives to CODEV, as well as Freedom of Information (FOI) requests regarding the negotiations of the document to three like-minded countries: the United Kingdom, Denmark and Sweden. The FOI requests resulted in the provision of 38 official documents, including government logs, e-mails, letters, speaking notes and position papers from the CODEV negotiations as well as from politicians and ministers involved in the negotiations of the code of conduct. In addition, the analysis builds on relevant secondary literature and statements from key decision-makers in a number of relevant press outlets (Agence Europe, Development Today) and EU press releases.

\section{Contesting the EU's aid effectiveness reforms}

Then, to what extent and why does the like-minded states' contestation of the EU's aid effectiveness initiative concern questions of justice? In the following, I trace the negotiation process and analyse the main points of contestation that appeared during the negotiations as well as the ultimate agreement on the EU's code of conduct on complementarity and division of labour.

When the Commission proposed the code of conduct on donor coordination in 2007 , their main justification was that the aid policies of the member states created an unjust situation for recipients (Commission 2007). Some countries were widely funded (aid darlings) and others were under-funded (aid orphans). In addition, aid was considered to be spent inefficiently due to overlapping projects in some recipient countries. The Commission's initiative followed several statements indicating that coping with the issue of aid fragmentation was a central aim for the EU. In 2004 the Commission (2004, p. 9) noted: 
The reasons for strengthening coordination, as well as the approach to be adopted, have in principle remained the same since 1974. Co-ordination of Community and bilateral aid policies and programmes will help reducing the transactions costs for recipient countries and achieve better efficiency and impact of EU aid. By virtue of its position as the world's largest donor by far in financial terms, the Union should exercise leadership in the global aid processes.

Hence, the aim of the policy initiative was to enhance coordination among donors by making them reduce the amount of states they provide aid to as well as concentrating funds to fewer projects and sectors. This without reducing the total amount of funds that was provided, but rather by giving a larger amount of funds to fewer projects. In this way a recipient state would not have to report to for example ten different donors on funds provided to the water sector, but only two or three. The idea was that this would enhance the efficiency of the funds spent as well as reduce the so-called transaction costs for the recipient states.

While aid is often thought of in redistribution terms, the issue of donor coordination and harmonisation illustrates that questions of political justice are also relevant. In order to obtain a more just redistributional aid scheme, reforms of the system affect the prior question of how decisions and reforms are made. Who decides on how a fair reform of global aid distribution should be carried out? These prior questions of who should be participating in the reforms and who should be in control over the final decision of how to coordinate became central elements of the negotiation process. The discussion was connected to the principle of 'ownership' in development policy, which reflects the view that beneficiary partners should be the central drivers of their own development trajectory and make their own decisions.

\section{Recipient ownership at the expense of universal solutions}

The principle of recipient ownership was proposed as a remedy to donor domination over beneficiaries and emerged as a central element of OECD-DAC's aid effectiveness reforms at the beginning of the century. The principle was first codified in the 2005 Paris Declaration on Aid Effectiveness (OECD 2005):

Ownership: Developing countries set their own strategies for poverty reduction, improve their institutions and tackle corruption.

In addition, the principle of alignment was proposed to secure that donors aligned with developing countries' priorities and supported their strategies: 'donor countries align behind these objectives and use local systems' (OECD 2005). Since Paris, country ownership, and how to achieve it, has been a central topic of discussion among practitioners and policy-makers worldwide. Its most basic interpretation highlights the need for actors affected by the policy to have a say in decisions that are being made. 
Including ownership as a principle in the EU's donor coordination policy was high on the agenda for the like-minded countries during the negotiations of the code, and they were surprised and concerned that it was not included in the Commission's original proposal. The like-minded held the view that the beneficiaries had an equal right to participate in the discussions on how donors should coordinate and harmonise as the donors themselves, as these countries were the ones that would be most affected by the change in policies.

The argument that the Commission's proposal needed to be altered to include and highlight the importance of the ownership principle is visible across all the documents of the like-minded states (FOI DK 2007a, 2007b, 2007c, 2007d, 2007e; FOI SW 2007a, 2007b, 2007c, 2007d; FOI UK 2007a, 2007b, 2007c; Utrikesdepartementet 2007). These are some typical examples of the like-minded's view:

The donors cannot simply distribute countries and sectors without involvement of the recipient countries [...] revealing the preferences of the recipient countries and identifying the comparative advantage of the donors will be crucial elements in the efforts to secure a better division of labour.

(FOI DK 2007a)

[...] emphasises the importance of the role of developing partner governments in determining the framework for donor support and identifying preferred partners and calls for building on current in-country initiatives and is open to all donors.

(FOI UK 2007c)

At first sight, the emphasis on including all affected parties in the decision-making process reflects an interpretation of donor coordination in line with a conception of justice as mutual recognition. To find the best possible solution, it was necessary to give all affected parties a due hearing - an opportunity to be heard in the coordination process. The like-minded emphasised that while coordination concerned donors' policies, the beneficiary countries were the main actors affected by the proposed reform.

Interviews with like-minded representatives corroborate that ownership was a central part of the discussion during the CODEV meetings. Like-minded representatives justified their scepticism toward the Commission's proposal on the grounds that it did not sufficiently reflect the need for giving recipients a voice in the process:

The first principle is the primary leadership and ownership, in-country division of labour should be with the partner-country government [...] we support the idea of presenting the EU as one, as a big player, but not led by the Commission only, led with the partners as well. 
We look at it as a partner government to government relation, where we first have a policy dialogue, we agree on the fact of what we want to do in the country, and then we conduct specific policies [...] we have totally different angle of pursuing development policy than many other countries.

$(\mathrm{MS}-2)$

The like-minded's main opponents, the Southern member states, held another view. Ownership was not emphasised or considered important to include in the EU's policy. Rather, they wanted a strong Commission in order to ensure that coordination would be implemented efficiently. For the Southern member states the most important concern was to achieve coordination in order to change the current situation. In their view, including recipients could lead to increased coordination problems (MS -3, -5, $6,-9 ; \mathrm{COM}-2$ ). Some interviewees were even sceptical of giving recipients a larger role: 'Sometimes governments like to play with donors, and this should be avoided because of things like corruption - so donor coordination is very important' (MS -8). The Commission's initial proposal and the Southern member states' perspective reflect a conception of justice as impartiality. The Southern states' arguments reflect the view that coordination of donors' policies could be considered a common good acceptable from the view of all affected parties. For these countries, the central concern was to secure a common solution and to delegate power to the Commission to effectively force the like-minded states to coordinate.

\section{Contesting the Code of Conduct}

As highlighted above, ownership of aid coordination, or the right to recipient participation, became a central point of disagreement during the negotiations of the code. The like-minded countries argued for the inclusion and emphasis of recipient ownership in the code, while the Southern countries supported the Commission's view that coordination should mainly be a task for the Commission, in order to make sure that coordination was effectively implemented.

During the policy-making process, there was one specific suggestion that caused the like-minded countries to reject the Commission's (2007) initial proposal. This suggestion was to limit donor presence to two sectors in each recipient country, also known as 'in-country complementarity'. The Commission originally proposed that donors should concentrate their activities to maximum two sector per country, for example health and education: 
Guiding principle 1 - Concentrate their activities in-country on focal sectors: EU donors will focus their activities on two focal sectors on the basis of their respective comparative advantages [...] In addition to the two focal sectors, which should absorb the bulk of available funding, donors can provide general budget support, where conditions permit to do so, and finance activities in other areas such as support to civil society, research, or university/school co-operation.

(Commission 2007)

The like-minded countries vigorously opposed to limit in-country activities to two sectors (MS-1, -2, -3, -4, -5, -6, -7, -8, -9; COM -1, -2, -3, -4). In their justifications for opposing this point, like-minded interviewees emphasised the need for recipients to participate in the decision of sector concentration. They argued that if donors were to reduce the number of countries they were to be involved in, it might be necessary to maintain support for a wide range of sectors in some important partner countries (MS $-1,-2,-7)$.

Out of the like-minded countries, the UK was the state that most strongly opposed the Commission's proposal. This is visible in the UK's documents as well as confirmed by interviewees with like-minded representatives. Gareth Thomas, the UK Parliamentary Under-Secretary of State at the Department for International Development (DFID) noted the following in an explanatory memorandum to DFID in mid-April 2007:

The code sets targets for the number of donors in each sector, and number of sectors in which each donor should engage. However, for a group of donors as varied as the EU it will be difficult to find a target equally appropriate and relevant for all. Some donors are active in only one or two sectors now, while others are active in a wide range of sectors. A target of two sectors would be particularly difficult to implement for some UK programmes so to retain flexibility the Government will negotiate to try to remove the specific reference to any particular number of sectors from principle one.

(FOI UK 2007c)

The issue of in-country complementarity was also widely discussed in the UK's domestic institutions. For instance, in a debate in the UK House of Commons European Standing Committee, Gareth Thomas explained the UK's position:

We have sought amendments to the document to recognise the situation that we face as a donor: in some of our key countries we work in nine different sectors. Clearly, some developing countries' governments will want donors who work in many sectors to maintain their spread in those sectors.

(House of Commons 2007) 
The issue of not restricting donor presence to two sectors proved to be so important to the UK that they threatened to not sign the policy (MS- 1, 2, 9). The UK's justifications for resisting the Commission's proposal are anchored in different argument. First, the UK highlights the need for differentiation (FOI UK 2007a, b, c; House of Commons 2007; MS-1). Both for donors and for the beneficiaries such differentiation is important, highlighted UK representatives. While they agree that a general scaling down of aid proliferation is important, it might be equally important to keep a certain range of activities in some countries. This view reflects the requirements set out by a conception of global justice as mutual recognition. In particular, the different experiences of donors and beneficiaries in their respective collaborations are given more importance than the common goal of reducing donor proliferation. Second, the UK questions the idea of assigning a 'neutral' institution, in this case the Commission, to decide on how donors should coordinate. In the UK's view, both donors and the beneficiaries would be the rightful authority to decide on where to scale down activities. These countries' experiences and expertise is a necessary condition for reaching sustainable reforms:

We would have been absolutely supportive of the idea that donors should be meeting with other donors, but it is very important that it is the government [recipient] that needs to establish the agenda. And then we should make sure that we are complementing their efforts.

(MS -1)

\section{Reaching an agreement}

After several CODEV meetings and discussions the member states found a solution. The UK, supported by the other like-minded states, managed to have a footnote added to the final version of the code of conduct:

In negotiations in Brussels late Thursday night, we agreed with other Member States to add the sentence approved by the PUSS as a general (i.e., not UKspecific) footnote to the Code of Conduct, prefaced by the text: 'In limited cases'.

(FOI UK 2007a)

The footnote that is referred to in the quotation reads as follows:

In limited cases, where donors face a significant reduction in sector coverage, this target may be increased to engage in more than three sectors, taking full account of partner countries' views, neglected issues of particular importance and a realistic timeframe to support any change in their country programmes.

(Council 2007) 
After the introduction of the footnote, the UK's negotiating representative reported to be satisfied with the outcome:

This is far more than we could have hoped for given the previous positions adopted by other member states and the Commission [...] We have avoided being isolated in rejecting an aid effectiveness commitment.

(FOI UK 2007a)

This statement shows the duality of the UK position. They did not oppose the overall goal of the policy but disagreed with parts of the content to the extent that it made them reluctant to participate. Further, the UK Ministerial Submission highlights that a strict rule of a maximum of two or three sectors for each donor would not necessarily be considered appropriate neither by the donor nor by the recipient:

We have ensured that we retain the flexibility to respond to partner country requests by specifying that donors will need to be active in more than three sectors in certain circumstances.

(FOI UK 2007a)

Although the UK was the primary country resisting the Commission's proposal of incountry complementarity, concerns similar to those voiced by the UK, are traceable in the positions of other like-minded member states:

The needs, priorities and leadership of partner countries should be the guiding principle for increased division of labour at the national level. [...] Flexibility that reflects the local context must be continuously ensured.

(FOI SW 2007b)

The like-minded states' contestation reflects the view that it is important to take into account the particular interests and experiences of both donors and beneficiaries when deciding on sector concentration of aid. In line a conception of justice as mutual recognition, a rule of maximum two-three sector involvements is considered unfortunate, because it would close the opportunity to respond to beneficiaries' different needs and preferences. Furthermore, these particular experiences of donor-beneficiary relations vary across countries, which justifies the need for differentiated solutions. As such, the like-minded countries allude to a central requirement set out by a conception of justice as mutual recognition, namely differentiated responsibilities and solutions. They contest the idea of finding a universal and unbiased reform that would suit all donorrecipient relations. Ownership, for the like-minded, is seen as a key to maintain reforms in line with recipient countries' needs and preferences.

In sum, the like-minded's position reflects an awareness of the need to recognise difference and autonomy. The proposal of one standard solution was not accepted. To 
find the best solution, it was necessary to hear the viewpoints of all affected parties. For the Southern member states, on the other hand, a strong Commission was crucial to ensure that member states really worked better together. This position reflects the viewpoint that it is possible to find one neutral and un-biased solution to donor coordination. It rests on the view that authoritative institutions can take the role of interpreting and enforcing commonly agreed norms that in principle may be seen as justifiable from the perspectives of all. There are, however, some ambiguities connected to the like-minded's interpretation of the ownership principle (which eventually became the EU's position as well). This is what I turn to in the next section.

\section{Democratic ownership?}

The analysis shows that the like-minded's resistance to integration mainly resulted from a conflict of normative concerns regarding how donor coordination could best be achieved. The like-minded's plea for ownership in the coordination process trumped the Southern member states' preference for a neutral and unbiased solution with set targets for concentration of aid. However, the arguments and solutions that were presented during the negotiations of the code of conduct also show that there are certain limits to the like-minded and the Southern member states' positions from a global political justice perspective.

In the negotiations, the like-minded states insisted on the inclusion of the recipient ownership principle in order to agree to the EU's policy. This was a central element of discussion during the Finnish presidency of the Council in the autumn of 2006. The issue was thoroughly discussed during the general affairs Council in Luxembourg in mid-October 2006 and the Council conclusions following from the meeting reflects the agreement reached on the importance of including ownership in the EU's aid effectiveness reforms:

The primary leadership and ownership in in-country division of labour should first and foremost lie in the partner country governments. If such leadership and ownership do not exist, the EU should advance such a process. In any case, the EU should always play an active role in promoting complementarity and division of labour. All initiatives need to be open for other donors, built on existing processes whenever possible, and readily transferred to the government whenever appropriate. The EU should provide capacity building support to the partner countries to enable them taking the responsibility.

(Council 2006)

Yet, the like-minded's call for increased recipient ownership in donor coordination processes reflects certain limitations. Their interpretation seems to rest on a narrow understanding of ownership, tied to recipient authorities. For instance, UK parliamentary Under-Secretary of State for International Development Gareth Thomas 
emphasised the need for country ownership in the following way in a debate in the UK parliament in May 2007:

The intention is for the developing country's Government to be in the driving seat. If that Government were to say, 'We want this particular donor to lead' we would expect and hope that other donors would be willing to follow that donor's lead.

(House of Commons 2007)

Similarly, the Danish position in the Council was presented in the following way:

The Danish Government holds, that the will to development within recipient countries is decisive for progress, and therefore we hold that recipient countries should be fully included in the decisions regarding complementarity.

(FOI DK 2007a - my translation)

The above quotes reflect a call for ownership understood as including the aid-recipient country's authorities in decisions on aid effectiveness. However, ownership, if limited to ownership by the recipient government, might not be enough to secure all affected parties a due hearing and differentiated solutions. In states with authoritarian traits, ownership may become narrow, even excluding a majority of stakeholders (Hasselskog \& Schierenbeck, 2015). The like-minded representatives' concern can be interpreted in line with the view that it is enough to have the recipient country on board on aid effectiveness decisions. Such an interpretation of ownership is what Cramer et al. (2006, p. 422) define as a 'co-operative partnership between the government and development funders' without a requirement of government consultation with its people. The alternative, national ownership, requires ownership to 'arise in a context of credible consultation with national stakeholders'.

As argued above, the like-minded member states managed to get their view accepted by the Commission and the Southern member states during the negotiation process. This is visible in the final document where several of the like-minded's preferred formulations are inserted. The Code opens with a paragraph defining the general principles the EU and its member state commit to. The Code confirms the interpretation of ownership as being mainly a task for the beneficiaries' governments: 'the primary leadership and ownership in in-country division of labour should first and foremost lie in the partner country government' (Council 2007).

This interpretation of ownership, as recipient government ownership, was also a central characteristic of the EU's development policy more widely, at the time. The EU consensus on development (European Communities 2006) coins ownership by partner countries as a common principle. Support for civil society and their vital role in promoting democracy, human rights and justice is highlighted, however not in connection with ownership. Another way in which the EU's narrow interpretation of ownership is visible is their wide use of budget support, an aid modality where funds are transferred 
directly to a recipient state budget without earmarks (Koeberle, Stavreski, \& Walliser, 2006). The provision of budget support combined with emphasis on the ownership principle can be seen as an attempt of donors to move away from paternalistic charity and move towards a more equal partnership. Aid, often criticised for causing dominating practices has resulted in reduced legitimacy for donors. The EU's emphasis on recipient country ownership can thus be understood in this wider context of a search for new legitimacy of current aid practices. Partner countries have more knowledge about the context than donors, hence they are also in a better position to decide upon a country's development strategy.

Yet, the like-minded's calls for increased ownership of development policies do not reflect the call for active dialogues with all affected parties and the need to take into account different groups' experiences and interests as required by an understanding of justice as mutual recognition. Rather, the EU's call for recipient ownership rather reflect an understanding where the recipient state (government) is expected to efficiently balance the interests and opinions of its citizens. Hence, such an understanding and interpretation of the recipient ownership principle might be more in line with the conception of justice emphasising state authority (non-domination) than with a conception of justice that recognises difference (mutual recognition). Consequently, one might also question the extent to which the solutions that are possible to find within the parameters of a conception of justice as non-domination go far enough to meet the aim of supporting recipient ownership.

\section{Conclusion}

Development aid is a phenomenon that casts light on issues of global political justice. Donors' unwillingness to coordinate their distribution of aid has led to dominating practices for developing countries. The wider aid effectiveness agenda was a multilateral effort to counter the domination that followed from donors' decision to provide large amounts of aid to some countries, aid darlings, and overlook others, aid orphans. Aid effectiveness reforms hence go beyond distributional concerns and affect the question of who decides on how these reforms should be carried out.

This paper's starting point has been that competing views on aid effectiveness reforms were central to the like-minded states' resistance of the EU's reform proposal. Applying a global political justice perspective, I make use of the conception of justice as impartiality to conceptualise central elements of the EU's proposal, and further on the concepts of justice as mutual recognition and justice as non-domination to understand the like-minded's resistance to the EU's approach. The analysis shows that the likeminded countries contested the EU's proposal on the grounds of the Commission not including the principle of recipient ownership in its reform. The like-minded states' main opponents in the negotiation, the Southern member states, held a different view. They made a plea for a neutral and unbiased solution effectively enforced by the Commission and questioned the partner countries' legitimate right to participate in decisions on donor coordination. The negotiations ultimately landed in favour of the 
like-minded states' position, something that supports the thesis of so-called likemindisation of EU development policy (Elgström, 2016; Elgström \& Delputte, 2016; Olsen, 2013).

The paper contributes to the general debate regarding normative commitments in the EU's foreign policy, by pointing to strengths and weaknesses of the Union's efforts to contribute to a less dominating system of global aid distribution. One the one hand, the like-minded countries argued for including recipients in future decisions on aid coordination among donors. On the other, these countries' position seems to be limited to ownership by recipient governments. This reflects a narrow interpretation of the principle of giving all affected parties a due hearing and falls short of standards for democratic ownership. Without a wider process of national consultation and accountability both on the donor and recipient side it is difficult to see how a strengthened government to government relationship will enhance citizens' freedom from domination.

The limitations of the EU's interpretation of ownership as government to government relations, is also of relevance to more recent $\mathrm{EU}$ efforts to create a new partnership with Africa. Recent statements from the EU emphasises the aspiration to support 'African solutions for African problems' and to create 'a partnership of equals with Africa' (EEAS 2019). The aim of moving away from donor-recipient relations and creating a 'real' partnership with developing countries from Africa, Caribbean and the Pacific (ACP) features prominently in the EU's mandate in the post-Cotonou negotiations (Commission 2016). When Commission President Jean Claude Juncker gave his final state of the Union address to the European Parliament in Strasbourg 12 September 2018, he stated the following about the EU's relationship with Africa:

We need to invest more in our relationship with the nations of this great and noble continent. And we have to stop seeing this relationship through the sole prism of development aid. Such an approach is beyond inadequate, humiliatingly so [...] Africa does not need charity, it needs true and fair partnerships. And Europe needs this partnership just as much.

(Juncker quoted in Euractiv 2018)

Yet, if the EU aims to move beyond donor-recipient relations and create a new and equal partnership with Africa, prioritising recipient governments over a broader democratic ownership process will not suffice. To be able to rectify challenges of donor domination, a broader dialogue with civil society and national stakeholders must be institutionalised as an integral part of the new partnership. The EU's track record of prioritising recipients' authorities in donor coordination questions whether the Union will live up to its aims.

The discussion regarding the EU's interpretation of the ownership principle also points to the value of analysing the EU's development policy from a global political justice perspective. Traditional international relations theory often draws on a conceptual distinction between idealistic and self-interested donors (Easterly, 2006; Lumsdaine, 
1993; Moyo, 2009). While these conceptions are a helpful starting point, a global justice perspective helps us move beyond so-called 'idealist motivations' for aid and create analytical standards that nuance our understanding of the competing normative claims that donors make in their aid-policies. By developing expectations from the three conceptions of justice it is possible to analyse the different normative arguments presented in the negotiation process of the EU's aid effectiveness reform and inquire into the extent to which they reflect requirements of global justice standards. 


\section{Sources}

\section{Interviews}

COM-1, Official, DG Devco, 11/8/16

COM-2, Official, DG Devco, 11/8/16

COM-3, Official, DG Devco, 31/8/16

COM-4, Manager, DG Devco, 1/9/16

COM-5, Official, DG Devco, 13/10/16

COU-1, Official, Council Secretariat, 31/8/16

MS-1, Member state official, 18/8/16

MS-2, Member state official, 30/8/16

MS-3, Member state official, 2/9/16

MS-4, Member state official, 12/9/16

MS-5, Member state official, 12/9/16

MS-6, Member state official, 14/9/16

MS-7, Member state official, 16/9/16

MS-8, Member state official, 21/9/16

MS-9, Member state official, 10/10/16

\section{Official documents and reports}

Action aid international (2007) Real aid: An agenda for making aid work. London, Action Aid International. Available at: http://www.actionaid.org.uk/doc lib/ 691 real aid.pdf

Agence Europe (2007) EU/Development: Fruitful Council Session for Africa and the Effectiveness of Development Aid, 15 May, Brussels: Agence Europe.

Council (2009) Council conclusions on an Operational Framework on Aid Effectiveness Brussels, 17 November 2009. Brussels: The European Council. Available at: http://aei.pitt.edu/46901/1/aid.effectiveness.oper framework.pdf

Council (2007) EU Code of Conduct on Complementarity and Division of Labour in Development Policy, Council document No. 9558/07, 15 May, Brussels: The European Council. Available at: https://register.consilium.europa.eu/doc/ srv? $=$ EN\&f=ST\%209558\%202007\%20INIT

Council (2006) Council Conclusions on complementarity and Division of Labour: preparations for the Orientation Debate on Aid Effectiveness. 2755th GENERAL AFFAIRS Council meeting Luxembourg, 17 October 2006. Available at: 
https://www.consilium.europa.eu/ueDocs/cms Data/docs/pressData/en/gena/91 330.pdf

Commission (2004) Communication from the Commission to the Council and the European Parliament. Translating the Monterrey consensus into practice: the contribution by the European Union. SEC (2004)246 / COM (2004)15ofinal, 5.3.2004. Brussels: European Commission. Available at: https://ec.europa.eu/ europeaid/communication-commission-council-and-european-parliamenttranslating-monterrey-consensus-practicethe en

Commission (2007) Communication from the Commission to the Council and the European Parliament. EU Code of Conduct on Division of Labour in Development Policy, COM(2007)72 Final, 28 February, Brussels: European Commission. Available at: https://ec.europa.eu/europeaid/sites/devco/files/communicationlabour-development-policy-code-of-conduct-com200872-20070228 en.pdf

Commission (2016) A renewed partnership with the countries of Africa, the Caribbean and the Pacific. Strasbourg, 22.11.2016 JOIN(2016) 52 final. Brussels: European Commission. Available at: https://ec.europa.eu/europeaid/sites/devco/files/jointcommunication-renewed-partnership-acp-20161122 en.pdf

Development today (2006) Utstein Alliance comes to an end. Available at: http://www.development-today.com/magazine/2006/DT 3/News/186

Euractiv (2018) Juncker offers EU-Africa trade deal in new 'partnership of equals', 12 September 2018. Available at: https://www.euractiv.com/section/africa/news/ juncker-offers-eu-africa-trade-deal-in-new-partnership-of-equals/

European Communities (2006) The European Consensus on development. Luxembourg: Office for official publications of the European Communities. Available at: https://ec.europa.eu/europeaid/sites/devco/files/publication-the-europeanconsensus-on-development-200606 en.pdf

EEAS (2019) The European Union's Global Strategy. Three years on, looking forward. Brussels: European Union. Available at: https://eeas.europa.eu/headquarters/ headquarters-homepage/64034/vision-action-eu-global-strategy-practice-threeyears-looking-forward de

FOI DK (2007a) Notat Hermed til specialudvalg kommenteret dagsorden Monterrey + Division of Labour, 1 July, Copenhagen: Danida.

FOI DK (2007b) Utviklingsministerens samtale med sin tyske kollega - EU Dagsordenen, 19 February, Copenhagen: Danida.

FOI DK (2007c) EU Code of Conduct for Complementarity and Division of Labour, 5 March, Copenhagen: Danida.

FOI DK (2007d) Instruktion: Møde I COREPER II d. 10.05.2007 - Code of Conduct on Complementarity and Division of Labour, 9 May, Copenhagen, Danida.

FOI DK (2007e) Letter from Ulla Tørnæs to Ms. Wieczorek-Zeul, 20 March, Copenhagen: Danida. 
FOI SW (2007a) instruction till mote I Allmänna Biståndgruppen måndag 30 april, 30.04.2007, Stockholm: Utrikesdepartementet.

FOI SW (2007b) Rapport från mote den 23 april 2007 I Allmäna biståndsgruppen, 24.04.20007, Brussel: Swedish Delegation to the EU.

FOI SW (2007c) Instruktion inför mote I Allmänna biståndgruppen den 4 april 2007, 03.04.2007, Stockholm: Utrikesdepartementet.

FOI UK (2007a) DFID Ministerial submission dated 27 April 2007 about how to ensure that the code of conduct allows DFID the flexibility to respond to developing countries' needs, 27 April, London: DFID.

FOI UK (2007b) Technical Seminar on EU Division of Labour, Brussels 30-31 January 2007, 1 February, London: DFID.

FOI UK (2007c) Explanatory memorandum on a European Community Document. Submitted by the Department for International Development, 19 April, London: DFID.

House of Commons (2007) EU Development Policy, Debate in the European Standing Committee, 8 May, London: House of Commons.

OECD (2005) The Paris declaration on aid effectiveness. Paris: OECD. Available at: http://www.oecd.org/dac/effectiveness/parisdeclarationandaccraagendaforaction. $\underline{\mathrm{htm}}$

OECD (2008) Accra Agenda for Action. Paris: OECD. Available at: http://www.oecd. org/dac/effectiveness/parisdeclarationandaccraagendaforaction.htm

Nordic Plus (2005) Nordic+ Complementarity Principles. Danida. November 2005.

Nordic Plus (2006) Nordic Plus Practical guide to delegated cooperation. October 2006. Oslo: Norad

Nordic Plus (2007) Practical guide to joint financing arrangements. October 2007. Oslo: Norad.

Brouwers, R, T. Kliest and B. Limonard (2008). Ahead of the crowd? The process of implementing the Paris Declaration. Case study: the Netherlands. Report produced for the synthesis of the results of the first phase of the evaluation of the Paris Declaration (27 February 2008), Policy and Operations Evaluation Department (IOB), Netherlands Ministry of Foreign Affairs. Available at: http://archief.iobevaluatie.nl/ParisDeclarationNetherlands.html

Utrikesdepartementet (2007) EU’s uppförandekod för arbetsfördelning på området utvecklingspolitik, Utrikesdepartementet 14 May, Stockholm: Utrikesdepartementet. 


\section{References}

Ayittey, G. (2010). An African Solution. Saving the Crisis of Failed States. Harvard International Review 31(3): 24-27.

Carbone, M. (2008). Mission Impossible: The European Union and Policy Coherence for Development. Journal of European Integration, 30(3), 323-342.

Carbone, M. (2013a). Between EU Actorness and Aid Effectiveness: The Logics of EU Aid to Sub-Saharan Africa. International Relations, 27(3), 341-355.

Carbone, M. (2013b). Foreign Aid, Donor Coordination and Recipient Ownership in EU-Africa Relations. In M. Carbone (ed.), The European Union in Africa: Incoherent Policies, Asymmetrical Partnership, Declining Relevance? Manchester: Manchester University Press.

Carbone, M. (2017). Make Europe Happen on the Ground? Enabling and Constraining Factors for European Union Aid Coordination in Africa. Development Policy Review, 35(4), 531-548.

Charnoz, O., \& Severino, J.-M. (2007). L'aide publique au développement. Paris: Editions La Découverte.

Cramer, C., Stein, H., \& Weeks, J. (2006). Ownership and Donorship: Analytical Issues and a Tanzanian Case Study. Journal of Contemporary African Studies, 24(3), 415436.

Delputte, S., \& Orbie, J. (2014). The EU and Donor Coordination on the Ground: Perspectives from Tanzania and Zambia. European Journal of Development Research, 26, 676-691.

Delputte, S., \& Söderbaum, F. (2012). European Aid Coordination in Africa: Is the Commission Calling the Tune? In S. Gänzle, S. Grimm, \& D. Makhan (eds), The European Union and Global Development: An 'Enlightened Superpower' in the Making? Basingstoke: Palgrave Macmillan.

Dworkin, R. (2011). Justice for Hedgehogs. Cambridge, MA: Harvard University Press.

Easterly, W. (2006). The White Man's Burden. Why the West's Efforts to Aid the Rest Have Done So Much Ill and So Little Good. Oxford: Oxford University Press.

Easterly, W., \& Pfutze, T. (2008). Where Does the Money Go? Best and Worst Practices in Foreign Aid. Journal of Economic Perspectives, 22(2), 29-52.

Elgström, O. (2016). Norm Advocacy Networks: Nordic and Like-Minded Countries in EU Gender and Development Policy. Cooperation and Conflict, 52(2), 224-240.

Elgström, O., \& Delputte, S. (2016). An End to Nordic Exceptionalism? Europeanisation and Nordic Development Policies. European Politics and Society, 16(1), 28-41.

Eriksen, E. O. (2016). Three Conceptions of Global Political Justice. GLOBUS Research Papers, 1/2016.

Hasselskog, M., \& Schierenbeck, I. (2015). National Policy in Local Practice: The Case of Rwanda. Third World Quarterly, 36(5), 950-966.

Hayter, T. (1971). Aid as Imperialism. Harmondsworth: Penguin Books. 
Horký, O. (2012). What Coherence between Foreign and Development Policy? In S. Gänzle, S. Grimm, \& D. Makhan (eds), The European Union and Global Development: An 'Enlightened Superpower' in the Making? Basingstoke: Palgrave Macmillan.

Ingebritsen, C. (2002). Norm Entrepeneurs: Scandinavia's Role in World Politics. Cooperation and Conflict, 37(1), 11-23.

Koeberle, S., Stavreski, Z., \& Walliser, J. (2006). Budget Support as More Effective Aid? Recent Experiences and Emerging Lessons. Washington D.C.: The World Bank.

Krook, M. L., \& True, J. (2012). Rethinking the Life Cycles of International Norms: The United Nations and the Global Promotion of Gender Equality. European Journal of International Relations, 18, 103-127.

Laborde, C. (2010). Republicanism and Global Justice: A Sketch. European Journal of Political Theory, 9(1), 48-69.

Lawler, P. (2007). Janus-Faced Solidarity. Danish Internationalism Reconsidered. Cooperation and Conflict, 42(1), 101-126.

Lumsdaine, D. H. (1993). Moral Vision in International Politics: The Foreign Aid Regime 1949-1989. Princeton, NJ: Princeton University Press.

Moyo, D. (2009). Dead Aid. Why Aid Is Not Working and How There Is Another Way for Africa. New York: Penguin.

Odén, B., \& Wohlgemuth, L. (2007). Svensk bistånds-politik $i$ ett internationellt perspektiv. Gothenburg: Centre for African Studies. Available at: https://www.gu.se/ digitalAssets/1238/1238481 Perspectives 1.pdf

Olsen, G. R. (2013). The European Union's Africa Policy: The Result of Nordicization or Europeanization? Journal of European Integration, 35(4), 409-424.

Orbie, J., \& Lightfoot, S. (2017). Development. Shallow Europeanisation? In A. Hadfield, I. Manners, \& R. Whitman (eds), Foreign Policies of EU Member States. Continuity and Europeanisation. London: Routledge.

Pettit, P. (2010). A Republican Law of Peoples. European Journal of Political Theory, 9(1), 70-94.

Pratt, C. (1989). Internationalism Under Strain: The North-South Policies of Canada, the Netherlands, Norway and Sweden. Toronto: Toronto University Press.

Puetter, U., \& Wiener, A. (2007). Accommodating Normative Divergence in European Foreign Policy Co-ordination: The example of the Iraq Crisis. Journal of Common Market Studies, 45(5), 1065-1088.

Saltnes, J. D. (2019). Resistance to EU Integration? Norm Collision in the Coordination of Development Aid. Journal of European Integration 41(4): 525-541.

Selbervik, H., \& Nygaard, K. (2006). Nordic Exceptionalism in Development Assistance? Aid Policies and the Major Donors: The Nordic Countries. CMI Report Bergen: Christian Michelsens Institue Available at: https://www.cmi.no/ publications/2371-nordic-exceptionalism-in-development-assistance

Short, C. (2000). Aid that Doesn't Help. Financial Times. 23 June.

Sjursen, H. (2017). Global Justice and Foreign Policy. The Case of the European Union. GLOBUS Research Papers, 2/2017. 
Smith, M. (2013). Foreign Policy and Development in the Post-Lisbon European Union. Cambridge Review of International Affairs, 26(3), 519-535.

Stokke, O. (1989). Western Middle Powers and Global Poverty: The Determinants of the Aid Policies of Canada, Denmark, the Netherlands, Norway and Sweden. Uppsala: Scandinavian Institute of African Studies.

Whitfield, L., \& Fraser, A. (2009). Introduction: Aid and Sovereignty. In L. Whitfield (ed.), The Politics of Aid. African Strategies for Dealing with Donors. Oxford: Oxford University Press.

Wiener, A. (2019). Contestation and Constitution of Norms in Global International Relations. Cambridge: Cambridge University Press. 
GLOBUS Research Papers

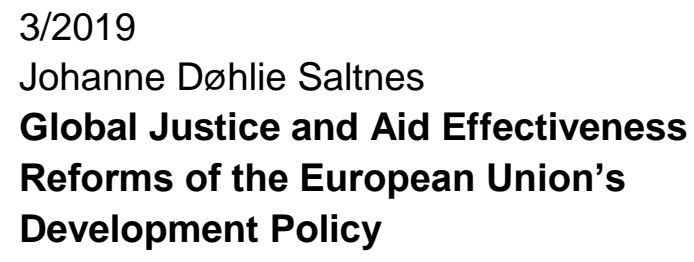

10/2018

Matthieu Burnay and Marta Hermez

Towards Global Justice with Chinese Characteristics

9/2018

Katie Verlin Laatikainen and Martin

Palouš

Contested Ground

The Campaign to Enhance the Status of the European Union in the UN General Assembly

$8 / 2018$

Hayley Walker

Mutual Recognition in Global

Negotiations

The Case of the 2015 Paris Climate

Summit

$7 / 2018$

Cathrine Holst

Promoting Global Justice when

Backlash Strikes

EU and UN Beijing +20

$6 / 2018$

Espen D.H. Olsen

Out but Still In

Norway's Approach to Migration and Asylum as a non-EU State

$5 / 2018$

Samuel Brazys and Krishna C.

Vadlamannati

Aid Curse with Chinese

Characteristics?

Chinese Development Flows and Economic Reform 
4/2018

Michela Ceccorulli

On Protection and Justice

The Proposals for Reform of the

Common European Asylum System

$3 / 2018$

Ben Tonra

The (In)Justices of Peacekeeping

EUFOR Tchad/RCA

$2 / 2018$

Nikola Tomić and Ben Tonra

The Pursuit of Justice through EU

Security Strategies

Sisyphus Redux?

$1 / 2018$

Alexa Zellentin

Different Angles on Climate Justice Insights from Non-domination and Mutual Recognition

\section{6/2017}

Mai'a K. Davis Cross

Europe's Foreign Policy and the Nature of Secrecy

\section{$5 / 2017$}

Bettina Ahrens

The Solidarisation of International

Society

The EU in the Global Climate Change

Regime
$4 / 2017$

Mai'a K. Davis Cross

EU Institutions and the Drive for Peace The Power of Ideas

$3 / 2017$

Kjartan Koch Mikalsen

Equal Sovereignty

On the Conditions of Global Political Justice

2/2017

Helene Sjursen

Global Justice and Foreign Policy

The Case of the European Union

$1 / 2017$

Franziskus von Lucke

O Justice, Where Art Thou?

Developing a New Take on Climate

Justice

$1 / 2016$

Erik O. Eriksen

Three Conceptions of Global Political Justice 


\section{GLOBUS Research Papers}

The GLOBUS Research Papers are pre-print manuscripts on the EU's contribution to global justice as well as the wider question of Global Political Justice. The series is multidisciplinary, with a particular emphasis on the fields of international relations, political science, political theory, sociology and law.

\section{Reconsidering European Contributions to Global Justice - GLOBUS}

GLOBUS is a research project that critically examines the European Union's contribution to global justice. Challenges to global justice are multifaceted and what is just is contested. Combining normative and empirical research GLOBUS explores underlying political and structural obstacles to justice. Analyses of the EU's positions and policies are combined with in-depth studies of non-European perspectives on the practices of the EU. Particular attention is paid to the fields of migration, trade and development, cooperation and conflict, as well as climate change. GLOBUS' team of researchers covers the disciplines of politics, international relations, law, economics, sociology and political theory. The project is coordinated by ARENA Centre for European Studies at the University of Oslo and has partners in Brazil, China, Germany, India, Ireland, Italy and South Africa. It is funded by the Horizon 2020 Programme of the European Union for the period 1.6.2016 - 31.5.2020.

\section{Series Editor}

Helene Sjursen, ARENA Centre for European Studies, University of Oslo GLOBUS Coordinator

\section{Editorial Board}

Thomas Diez

Erik O. Eriksen

Sonia Lucarelli Pundy Pillay

Ben Tonra
Institute of Political Science, University of Tübingen ARENA Centre for European Studies, University of Oslo Department of Political and Social Sciences, University of Bologna Wits School of Governance, University of Witwatersrand School of Politics and International Relations, University College Dublin 